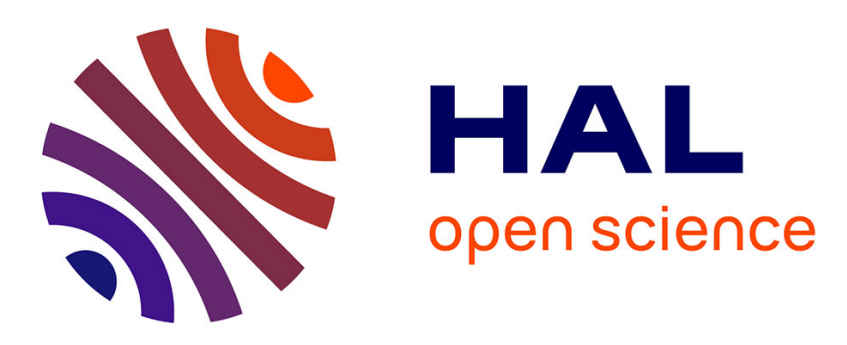

\title{
Habitat diversity associated with island size and environmental filtering control the species richness of rock-savanna plants in neotropical inselbergs
}

Ludovic Henneron, Corinne Sarthou, Jean-Christophe de Massary, Ponge Jean-François

\section{To cite this version:}

Ludovic Henneron, Corinne Sarthou, Jean-Christophe de Massary, Ponge Jean-François. Habitat diversity associated with island size and environmental filtering control the species richness of rocksavanna plants in neotropical inselbergs. Ecography, 2019, 42 (9), pp.1536-1547. 10.1111/ecog.04482 . hal-02276992

\section{HAL Id: hal-02276992 \\ https://hal.science/hal-02276992}

Submitted on 3 Sep 2019

HAL is a multi-disciplinary open access archive for the deposit and dissemination of scientific research documents, whether they are published or not. The documents may come from teaching and research institutions in France or abroad, or from public or private research centers.
L'archive ouverte pluridisciplinaire HAL, est destinée au dépôt et à la diffusion de documents scientifiques de niveau recherche, publiés ou non, émanant des établissements d'enseignement et de recherche français ou étrangers, des laboratoires publics ou privés. 
1 Habitat diversity associated with island size and environmental filtering control the species

2 richness of rock-savanna plants in neotropical inselbergs

3 Ludovic Henneron, Corinne Sarthou, Jean-Christophe de Massary, Jean-François Ponge*

L. Henneron (https://orcid.org/0000-0002-3979-0543), Dept. of Forest Ecology and Management, Swedish University of Agricultural Sciences, Umeå, Sweden.- C. Sarthou (https://orcid.org/00000001-8238-3639), Institut Systématique Evolution Biodiversité (ISYEB), , Muséum National d'Histoire Naturelle, CNRS, Sorbonne Université, EPHE, 57 rue Cuvier, CP 39, 75005 Paris, France.- J. C. de Massary, UMS Patrimoine Naturel, Muséum National d'Histoire Naturelle, 36 rue Geoffroy SaintHilaire, CP 41, 75005 Paris, France.- J. F. Ponge (https://orcid.org/0000-0001-6504-5267) (jeanfrancois.ponge@mnhn.fr), UMR 7179, Muséum National d'Histoire Naturelle, CNRS, 4 avenue du Petit Château, 91800 Brunoy, France.

*Corresponding author

\section{Abstract}

Disentangling the multiple factors controlling species diversity is a major challenge in ecology. Island biogeography and environmental filtering are two influential theories emphasizing respectively island size and isolation, and the abiotic environment, as key drivers of species richness. However, few attempts have been made to quantify their relative importance and investigate their mechanistic basis. Here, we applied structural equation modelling, a powerful method allowing test of complex hypotheses involving multiple and indirect effects, on an island-like system of 22 French Guianan neotropical inselbergs covered with rock-savanna. We separated the effects of size (rock-savanna area), isolation (density of surrounding inselbergs), environmental filtering (rainfall, altitude) and dispersal filtering (forest-matrix openness) on the species richness of all plants and of various ecological groups (terrestrial versus epiphytic, small-scale versus large-scale dispersal species). We showed that the species richness of all plants and terrestrial species was mainly explained by the size 
of rock-savanna vegetation patches, with increasing richness associated with higher rock-savanna area, while inselberg isolation and forest-matrix openness had no measurable effect. This size effect was mediated by an increase in terrestrial-habitat diversity, even after accounting for increased sampling effort. The richness of epiphytic species was mainly explained by environmental filtering, with a positive effect of rainfall and altitude, but also by a positive size effect mediated by enhanced woodyplant species richness. Inselberg size and environmental filtering both explained the richness of smallscale and large-scale dispersal species, but these ecological groups responded in opposite directions to altitude and rainfall, that is positively for large-scale and negatively for small-scale dispersal species.

Our study revealed both habitat diversity associated with island size and environmental filtering as major drivers of neotropical inselberg plant diversity and showed the importance of plant species growth form and dispersal ability to explain the relative importance of each driver.

Keywords: Environmental filtering; Island biogeography; Island size; Isolation; Patchy habitats; Plant diversity; Tropical inselbergs; Structural equation modelling

\section{Introduction}

Understanding the multiple determinants regulating species diversity has long been a major theme in ecology, in particular within the fields of island biogeography and community ecology (MacArthur and Wilson 1967, Leibold et al. 2004). Plant species richness of vegetation patches has been shown to increase with patch area (Connor and McCoy 1979, Honnay et al. 1999, Van Noordwijk et al. 2015), patch heterogeneity (Huston 1999, Dufour et al. 2006), habitat amount (Lindgren and Cousins 2017), disturbance (Pickett 1980, Lavorel et al. 1994), mildness of the environment (Gray 1989, Fonty et al. 2009, Cheng et al. 2013), resource availability (Neri et al. 2017), size of regional species pools (Zobel 1997), and to decrease with patch isolation (Gadgil 1971, Hanski 1991, Martín-Queller et al. 2017). Those drivers of species richness could potentially have interactive effects and tradeoffs can exist among them (Allouche et al. 2012). Biotic interactions, internal to the plant community, may also modulate these effects, either negatively for competition or positively for facilitation (Houle and 
Phillips 1989). Disentangling the complex relationships between all these factors suffers from severe technical limitations, resulting in often partial or even erroneous conclusions when multiple theories are evaluated in isolation (Shmida and Wilson 1985, Laliberté et al. 2014). Among the methods that allow assessment of the relative importance of various factors and disentanglement of direct and indirect effects of these factors, structural equation modeling (SEM) is increasingly used as a powerful statistical framework to address those issues (Grace and Pugesek 1997, Gazol et al. 2012, Laliberté et al. 2014, Peppler-Lisbach et al. 2015).

Given their isolation within a landscape matrix and their distinctive abiotic environment supporting particular vegetation communities (Porembski et al. 1996, Prance 1996), inselbergs are good candidates for disentangling the various determinants of plant species richness in vegetation patches (Parmentier and Hardy 2009). Inselbergs are widespread on old crystalline shields and occur particularly in tropical and subtropical regions (Porembski and Barthlott 2000). Consisting of Precambrian granites and gneisses, they are defined as remnants of erosion processes forming isolated mountains which rise from the surrounding landscape (Bremer and Sander 2000). They can range in elevation from a few to several hundred meters and their size ranges from a few square meters to several square kilometers (Bremer and Sander 2000). They are characterized by harsh conditions including a high degree of insolation combined with high evaporation rates and locally very restricted soil occurrence, which in turn leads to rapid loss of rainwater by runoff (Porembski 2007, Szarzynski 2000). Due to these specific edaphic and microclimatic conditions, inselberg vegetation is clearly distinct from that of their surroundings, forming an island-like ecosystem (Itescu 2018). In particular trees, which form the bulk of the vegetation of the surrounding forest matrix, are replaced by lowstature woody species highly tolerant of shallow soils, and shade-tolerant plant species are replaced by light-demanding species (Porembski et al. 1997).

In French Guiana, inselbergs embedded in the rain forest are covered with discontinuous vegetation forming a type of mosaic locally called rock-savanna. This vegetation is characterized by numerous scattered herbaceous and shrubby patches separated by bare rock (de Granville 1978, Sarthou 1992, Sarthou and Villiers 1998, Sarthou et al. 2003). Rock-savanna vegetation is kept in a dynamic state by 
erosion and fire events (Kounda-Kiki et al. 2008, Sarthou et al. 2009). It undergoes extreme local climate variation during day-night cycles: high and frequent variations in temperature $\left(18-55^{\circ} \mathrm{C}\right)$ and relative humidity (20-100\%; Sarthou 1992). Soils are generally shallow and acid, with low waterholding capacity (Sarthou and Grimaldi 1992). At the scale of the whole French Guianan territory, the distribution of inselberg plant species and their traits is mostly driven by a spatially-structured gradient embracing regional climate, forest matrix and inselberg features and the variation observed at coarse scale is explained by biogeographic, environmental and past historical factors, such as savannization (Sarthou et al. 2017). Despite numerous attempts to explain the floristic composition of neotropical inselbergs by adaptive traits of rock-savanna plant species (Shure and Ragsdale 1977, de Granville 1982, Houle and Phillips 1989, Ibisch et al. 1995, Meirelles et al. 1999, Sarthou et al. 2003, Parmentier and Hardy 2009, Sarthou et al. 2017), much still needs to be known about the determinants of plant-species diversity in these ecosystems (Porembski et al. 2000b).

In this study, we aimed at investigating the multiple drivers of plant species diversity in French Guianan inselberg rock-savanna ecosystems. The factors considered here include rock-savanna vegetation area, isolation from surrounding inselbergs, the number of habitats this vegetation type featured, rainfall, altitude, as well as openness of the surrounding forest matrix. We used a network of 22 inselbergs located throughout French Guiana and featuring contrasting environmental conditions and inherent characteristics (Fig. 1, Table 1). We applied structural equation modeling as a tool to test simultaneously multiple hypotheses about the drivers of plant species diversity as well as to disentangle the direct and indirect mechanisms involved (Grace and Pugesek 1997). Based on a priori knowledge of the studied ecosystem and ecological theories, four distinct hypotheses were tested (Fig. 2). The first hypothesis is related to island size (area of rock-savanna vegetation on inselbergs), the second to island isolation (density of the surrounding inselbergs), the third to environmental filtering (rainfall and altitude) and the fourth to dispersal filtering (openness of the surrounding forest matrix). $\mathrm{H}_{1}$ : Inselbergs of larger rock-savanna vegetation area harbour higher plant diversity, either directly $\left(\mathrm{H}_{1 \mathrm{a}}\right)$ by allowing the establishment of more individuals (Connor and McCoy 1979) and by reducing stochastic extinction rate (Lindgren and Cousins 2017), and/or indirectly $\left(\mathrm{H}_{1 \mathrm{~b}}\right)$ by promoting higher 
habitat diversity and heterogeneity (Dufour et al. 2006). This observation may also be trivially related to higher sampling effort $\left(\mathrm{H}_{1 \mathrm{c}}\right)$. $\mathrm{H}_{2}$ : Higher density of surrounding inselbergs promotes higher plant diversity of a given inselberg by enhancing immigration rate due to larger number of colonisation sources (Moritz et al. 2013). $\mathrm{H}_{3 \mathrm{a}}$ : Higher rainfall increases the diversity of epiphytes by enhancing moisture (Cardelús et al. 2006) and that of large-scale dispersal (zoochorous) species by promoting higher abundance of dispersing animals (Correa et al. 2015), but it reduces the diversity of small-scale dispersal (autochorous) species by increasing water flow intensity on inselberg slopes (Isichei et al. 1990). $\mathrm{H}_{3 \mathrm{~b}}$ : Larger altitude at the top of inselberg increases the diversity of epiphytes by promoting long fog periods, and of large-scale dispersal (anemochorous) species by enhancing downslope winds, but it reduces the diversity of small-scale dispersal (autochorous) species due to steeper inselberg slopes (Obregon et al. 2011). $\mathrm{H}_{4}$ : Higher openness of the surrounding forest matrix increases the diversity of inselberg plant species by increasing permeability to immigration from the surroundings (Martín-Queller et al. 2017).

\section{Material and methods}

\section{Study sites}

We studied 22 inselbergs (of which 15 are grouped in 4 archipelagos) scattered over the territory of French Guiana (Table 1, Fig. 1). As part of the Guiana Shield in northern Amazonia, French Guiana $\left(4^{\circ} 13^{\prime} \mathrm{N}, 52^{\circ} 59^{\prime} \mathrm{W}\right.$ ) covers about $85,000 \mathrm{~km}^{2}$ and has a mean altitude of about $140 \mathrm{~m}$ above sea level with few mountainous peaks exceeding $800 \mathrm{~m}$. Its basement, approximately $2.2-1.9 \mathrm{Gyr}$ in age, corresponds to the oldest and most homogeneous part of the Guiana Shield (Delor et al. 2003). Its climate is equatorial and is characterized by $3000 \mathrm{~mm}$ mean annual rainfall, distributed along a Northeast to Southwest gradient decreasing from about 4000 to $2000 \mathrm{~mm}$ (Sarthou et al. 2017). Rainfall is concentrated mainly between December and July (Héritier 2011). Granitic inselbergs are mostly concentrated in southern and eastern parts of the territory (Fig. 1). In the extreme south, groups of elevated dome-shaped inselbergs border the Brazilian Amazon basin. The peneplain in the southern 
half of French Guiana is characterised by low elevation and slightly slanting rocky slags in a semiopen forest matrix. The northern half of French Guiana is covered with a dense rain forest with isolated dome-shaped inselbergs (Gond et al. 2011).

\section{Vegetation data}

We first carried out vegetation surveys in 20 inselbergs from 1988 to 2011. A comprehensive inventory of the vascular flora was undertaken on each inselberg. However, we excluded from the analysis species growing in the ecotone zone between rock-savanna and the surrounding forested matrix, and species growing in summit forests (when present). Consequently, the analysis was restricted to the "rock savanna” facies sensu stricto characterized by vegetation patches on bare rock. Each inselberg was sampled only once due to financial constraints. Given the difficult conditions for field work, the sites were only reached by helicopter. Nouragues was sampled in 1988, Dachine and Mont Chauve in 1997, Trinité A in 1998, Mitaraka in 2001, Bakra, Arawa and Saint Marcel in 2002, Wanapi and Marouini in 2004. Our goal was to carry the most exhaustive inventories possible during our presence on the field, with a unique methodology. The period from March to July was chosen because previous work showed it harboured a maximum of flowering plants (Sarthou 1992). Sampling effort was adapted to area and environmental heterogeneity of each site, and was included in the form of the number of person-days devoted to sampling.

The data set was completed for Trinité B (1981) and Virginie (1991) through an extraction from the Cayenne Herbarium data base available at http://publish.plantnet-project.org/project/caypub). The sampling effort devoted to Trinité B and Virginie by the collectors allowed us to consider these additional records as comprehensive and fully reliable.

The final data set comprised 391 species, including 73 epiphytes and 318 terrestrial plant species. Voucher specimens were deposited in the Cayenne Herbarium (CAY) and were registered in the Cayenne Herbarium database. Plant identification was performed according to Funk et al. (2007). We studied plant diversity as the species richness for the whole community but also of specific ecological groups, such as terrestrial (growing directly on bare rock or on shallow soils), epiphytic 
159 (growing on shrubs), small-scale dispersal (autochorous and barochorous), and large-scale dispersal

160 (wind- and animal-dispersed) plant species.

161

162

163

164

165

166

167

\section{Ecological drivers}

The area of rock-savanna vegetation was measured directly in the field or calculated from aerial photographs for the smallest inselbergs $\left(<0.1 \mathrm{~km}^{2}\right)$. The number of terrestrial habitats available on each inselberg was based on the list published by Porembski et al. (2000a) after refinement from field observations (Sarthou et al. 2017). For epiphyte species, the number of habitats on each inselberg was estimated by measuring the number of woody species. The number of person-days spent was used as a measure of sampling effort.

Mean annual rainfall values were interpolated for each site from the isoline map published by Héritier (2011). Maximum summital altitude of inselbergs (here called 'altitude’) was measured during field survey using a GPS device with an integrated high-resolution barometer. Inselberg density was estimated by the percent surface occupied by inselbergs within a $15 \mathrm{~km}$ radius, using the GIS program Mapinfo ${ }^{\circledR}$ version 9.0.

Canopy openness of the forest matrix surrounding each inselberg was calculated from remotesensing data (Gond et al. 2011). We pooled categories RSLC 20, 21 and 22 of open and semi-open canopy forests, and measured their cover percentage within a $15 \mathrm{~km}$ radius.

\section{Statistical analyses}

We conducted all analyses separately for the richness of all plants, terrestrial and epiphytic as well as small and large-scale dispersal plant species. Bivariate relationships between plant diversity and ecological drivers were assessed using Spearman's correlation coefficients (Table S1) as well as simple regression linear models with either linear, quadratic or power relationships (Table S2). Power regressions were modelled using log-log transformation. The selection of the set of terms yielding the best model goodness-of-fit was conducted by comparing models based on adjusted $\mathrm{r}^{2}$. 
We performed structural equation modelling (SEM) to investigate which ecological drivers influence species richness of inselberg rock-savanna vegetation. We used eight parameters as potential direct or indirect drivers of plant diversity (Table 1): rock-savanna vegetation area, habitat diversity, sampling effort, inselberg density, mean annual rainfall, maximum altitude, distance to the Atlantic coast and openness of the surrounding forest matrix. A causal diagram was first built based on ecological theories and our a priori knowledge of the system (Fig. 2). We used the number of terrestrial habitats as a measure of habitat diversity for all ecological groups except epiphytic species, for which the number of woody species was used as a measure of habitat diversity instead.

We adopted a local-estimation approach based on piecewise fitting of component linear models. Normal distribution and homogeneity of variances of the residuals of each component model of the global path model were checked graphically. We adopted a model-selection approach using information-theoretic methods. First, we selected the best set of plant diversity predictors by comparing multiple regression models comprising all possible combinations of predictors using the Akaike Information Criteria corrected for small sample size (AICc). This allowed us to establish a confidence set of models with $\triangle \mathrm{AICc}<2$ from all possible combination of the 7 factors (Burnham and Anderson 2002). To avoid multicollinearity, models with variance inflation factors (VIF) $>10$ were excluded from the confidence models set (Dormann et al. 2013). Then, we removed all the paths toward plant richness representing factors not included in the best multiple regression model selected during the initial step (Table S3). All variables no longer related to plant diversity and their paths were also removed as well as non-significant paths. At each removal step, SEM model goodness-of-fit was assessed by Shipley’s d-sep test (Shipley 2009) and the AICc computed following Shipley (2013). We applied this selection procedure until we found the most parsimonious SEM model.

All statistical analyses were performed using R software version 3.1.2 with the packages MuMIn and piecewiseSEM. All statistical tests were realized with $\alpha=5 \%$. 


\section{Total plant species richness}

In accordance with hypothesis $\mathrm{H}_{1}$, the best fit SEM model showed that the species richness of all plants was exclusively explained by the size of inselberg rock-savanna vegetation patches (Fig. 3a), which explained $79.9 \%$ of variation (Fig. 4). Total plant species richness increased linearly with rocksavanna vegetation area (Fig. 3b). Direct size effect $\left(\mathrm{H}_{1 \mathrm{a}}\right)$ was not supported by the model. This size effect was indirect and mediated by habitat diversity and heterogeneity $\left(\mathrm{H}_{1 \mathrm{~b}}\right)$. The number of terrestrial habitats increased with rock-savanna vegetation area following a power function (Fig. 3c, Table S2). In turn, total plant species richness was positively associated with the number of terrestrial habitats following a power function (Fig. 3d, Table S2), even after accounting for the linear increase in sampling effort $\left(\mathrm{H}_{1 \mathrm{a}}\right.$, Fig. 3a, Fig. S1a). In contrast with hypothesis $\mathrm{H}_{2}$, total plant species richness was not related to inselberg density (Fig. 3e).

\section{Terrestrial versus epiphytic species richness}

Terrestrial species richness followed the general trend depicted by total plant species richness, with $78.6 \%$ of variation explained by rock-savanna vegetation area (Figs. 4, 5a). Terrestrial plant species richness increased with rock-savanna vegetation area following a power function (Fig. S2a). The positive effect of inselberg size was mediated mostly by the increase in habitat diversity $\left(\mathrm{H}_{1 b}\right.$, number of terrestrial habitats), which was positively associated with terrestrial plant species richness following a power function (Fig S2b).

Epiphytic species richness was explained by both inselberg size and environmental factors (Fig. 5b), to which environmental filtering contributed most (65.0 \%, Fig. 4). In accordance with hypothesis $\mathrm{H}_{3}$, rainfall $\left(\mathrm{H}_{3 \mathrm{a}}\right)$ and altitude $\left(\mathrm{H}_{3 \mathrm{~b}}\right)$ had a direct positive relationship with epiphytic species richness. As expected, rainfall was negatively influenced by distance to the Atlantic coast following a power function (Fig. S1b). Rainfall and altitude also had an indirect positive effect on epiphytic species richness through their positive relationship with woody plant species richness, which had a direct positive effect on epiphyte plant species richness (Fig. S3a). We also observed a positive relationship between the proportion of woody and epiphytic species within the community (Fig. S3b). Epiphytic 
plant species richness increased linearly with rock-savanna vegetation area (Fig. S2c). The positive effect of island size was both related to a direct stochastic size effect $\left(\mathrm{H}_{1 \mathrm{a}}\right)$, but also to an indirect effect through the increase of woody plant species richness with rock-savanna vegetation area $\left(\mathrm{H}_{1 \mathrm{~b}}\right.$, Fig. 5b). The effect of forest matrix openness $\left(\mathrm{H}_{4}\right)$ was not supported by the model.

\section{Large-scale versus small-scale dispersal species richness}

The richness of large-scale and small-scale dispersal species was explained by both size and environmental filtering (Figs. 4, 6). The species richness of both classes of dispersal ability was affected by the size of rock-savanna vegetation area, with a positive indirect effect mediated by the number of habitats $\left(\mathrm{H}_{1 \mathrm{~b}}\right)$ and by sampling effort $\left(\mathrm{H}_{1 \mathrm{c}}\right)$, similarly to total plant species richness (Fig. 3a). Altitude and rainfall contributed to a significant extent to the total variation in species richness, but in opposite direction whether dispersal occurred over large or small distances. Altitude and rainfall had negative effects on the richness of small-scale dispersal species (Fig. 6a), while they had positive effects on the richness of large-scale dispersal species (Fig. 6b), in accordance with hypothesis $\mathrm{H}_{3}$.

$$
\text { In order to better explain the above-mentioned discrepancy between the classes of species }
$$
dispersal ability, we analysed the correlation between altitude and rainfall with the contribution of each of the four dispersal syndromes to the total plant species richness (Fig. S4). We focused on terrestrial species only, because they are dominant (90\% of total plant species richness per inselberg on average) and better studied in the literature. The proportion of autochorous (small-scale dispersal) species within the community decreased when altitude increased (Fig. S4a), while that of anemochorous (large-scale dispersal) species increased (Fig. S4b). The proportion of species of the two other large-scale dispersal types (zoochorous and hydrochorous) remained unchanged (Figs. S4c,d). Similarly, the proportion of autochorous species decreased when annual rainfall increased (Fig. S4e), while the proportion zoochorous species increased (Fig. S4g). The proportion of species of the two other large-scale dispersal types (anemochorous and hydrochorous) remained unchanged (Figs. S4f,g). 


\section{Discussion}

The primary aim of our study was to investigate the drivers shaping plant diversity in island-like neotropical inselberg ecosystems by testing multiple hypothesis related to island size $\left(\mathrm{H}_{1}\right)$ and isolation $\left(\mathrm{H}_{2}\right)$ as well as environmental and dispersal filtering $\left(\mathrm{H}_{3}\right.$ and $\mathrm{H}_{4}$, Fig. 2).

In accordance with hypothesis $\mathrm{H}_{1}$, we found here that total plant species richness was positively related to the area of rock-savanna vegetation on inselbergs (Figs. 3a,b), even after controlling for sampling effort $\left(\mathrm{H}_{1 \mathrm{c}}\right)$. This positive size effect was observed whether plants considered are terrestrial or epiphytic (Fig. 5) and able to disperse over small or large-scale (Fig. 6), showing that island size was a major determinant of plant diversity (Fig. 4). This result is in agreement with ecological theories (MacArthur and Wilson 1967, Hanski 1989, Leibold et al. 2004) and is largely shared by many studies on isolated patches of vegetation (Price 2004, Peppler-Lisbach et al. 2015), especially on inselbergs (Porembski et al. 1996, Meirelles et al. 1999, Porembski et al. 2000b). Further, we showed that this positive size effect on species richness was not explained by a direct stochastic size effect $\left(\mathrm{H}_{1 \mathrm{a}}\right)$ (Connor and McCoy 1979), except for epiphytic species. For terrestrial species, the positive size effect was rather mediated by the increase in the diversity of terrestrial habitats present on a given inselberg ( $H_{1 b}$, Figs. 3c, d), in line with various studies on vegetation patches (Auerbach and Shmida 1987, Honnay et al. 1999, Dufour et al. 2006). The effect of habitat diversity was here related to floristic differences between habitats typical of rock-savanna vegetation, such as continuous rock surfaces, temporary ponds, crevices with their variants according to the presence of soil, rock or woody debris (Sarthou and Villiers 1998, Gröger and Huber 2007, Parmentier and Hardy 2009). For epiphytic species, the indirect size effect was mediated by the diversity of shrubs and lianas (Fig. 5b). Epiphytes need the bark of woody species as supports (Benzing 1981), and the degree of epiphytism is in direct proportion to the contribution of woody flora.

In contrast to hypothesis $\mathrm{H}_{2}$, we found that the density of surrounding inselbergs did not affect the species richness of rock-savanna plants covering a given inselberg (Fig. 3e), suggesting that inselberg plant species richness was not affected by the geographic isolation of inselbergs from others. 
287 Similarly, the cover of open-canopy forest matrix was never selected as a predictor of inselberg plant

288 species richness, in contrast to the hypothesis $\mathrm{H}_{4}$ that higher openness of the surrounding forest matrix

289 would increase plant diversity by increasing permeability to immigration from the surroundings. This

290 might indicate that rescue and mass effects (Shmida and Wilson 1985, Hanski 1991, Moritz et al.

291 2013) are here negligible. It means that whatever the presence of other inselbergs and the cover of

292 open-canopy forest in the vicinity of a given inselberg (for instance within the so-called archipelagos),

293 only its size and size-related factors (habitat diversity and sampling effort), as well as environmental

294 filters (rainfall and altitude), contribute to increase or decrease the total number of plant species it

295 harbours. While several studies showed that during drier periods of the Holocene savanna-like

296 vegetation covered large areas of the Guianan Shield (Servant et al. 1993, Freycon et al. 2010, Rull

297 and Montoya 2017), present-day rock-savanna vegetation should be considered as a relict constellation

298 of isolated fragments of xeric vegetation embedded in a more or less continuous rain-forest cover (de

299 Granville 1982, Prance 1996). Even inselbergs distributed in archipelagos do not seem to exchange

300 diaspores to a significant extent (Barbará et al. 2007, Pinheiro et al. 2014). The absence of any effects

301 of inselberg density on floristic richness was valid whatever the ecological group considered

302 (terrestrial versus epiphytic vegetation, small-scale versus large-scale dispersal types), pointing to the

303 paucity of dispersal and related mass/rescue effects (Leibold et al. 2004). This result supports at

304 community-level the results obtained at species level, showing poor gene flow among inselbergs

305 (Sarthou et al. 2001, Boisselier-Dubayle et al. 2010, Pinheiro et al. 2014). This was also apparent in

306 floristic composition. The flora of each inselberg located within Wanapi, Haut Marouini, Monts Bakra

307 and Trinité archipelagos was not influenced (either positively or negatively) by that of other members

308 of the same archipelago (Sarthou et al. 2017). However at local-scale, dispersal is an important driver

309 of biodiversity when in the presence of a patchwork of habitats and successional stages of the same

310 habitat (Porembski et al. 1997, Sarthou and Villiers 1998, Bruun et al. 2008). In inselbergs, where

311 disturbances occur at a high rate (lighting fires, violent storms, alternating phases of drought and

312 flooding), vegetation patches are submitted to rapid and pronounced changes, implying the

313 reconstruction of disturbed habitats through primary or secondary successional processes (Whitehouse 
1933, Shure and Ragsdale 1977, Sarthou et al. 2009). All these successional processes require seed dispersal for species establishment in safe sites (Houle and Phillips 1989, Biedinger et al. 2000).

In accordance with hypothesis $\mathrm{H}_{3}$, we found that environmental filtering was also a major determinant of species richness for epiphytic plants, explaining a larger portion of variance relative to the effect of size (65.0 versus $25.1 \%$ respectively, Fig. 4). The notion of environmental filtering $\left(\mathrm{H}_{3}\right)$ encompasses here how the local abiotic environment can filter the species pool directly by impeding species survival and persistance, and also indirectly by affecting dispersal agents and/or biotic interactions (Cadotte and Tucker 2017). Epiphytic species richness was strongly affected by both altitude and rainfall, itself determined by distance to the Atlantic Ocean (Fig. 5b). We observed that taller inselbergs with higher rainfall harboured more epiphytic species. Epiphytes are known to fulfil their moisture requirements through taking up water from mist, canopy drip and/or stem flow (Veneklaas and Van Ek 1990), and thus thrive at higher elevation and in higher-rainfall areas (Wolf and Flamenco-S 2003; Cardelús et al. 2006, Obregon et al. 2011). Further, we found that higher elevation and rainfall similarly favoured woody-plant richness, which had a beneficial effect on epiphytic species richness by increasing the diversity of their habitats (Fig. 5b). Given that rainfall and altitude have been shown to influence inselberg floristic composition (Sarthou et al. 2017), it can be argued that the absence of any effects of rainfall and altitude on terrestrial species richness (Fig. 5a) can be due to a balance between addition and deletion of species under the influence of these factors, without any resulting shift of terrestrial species richness (Ricklefs 1987). Indeed, we showed that altitude and rainfall exerted contrasting effects on plant diversity depending on species dispersal modes (Fig. 6). Autochorous (small-scale dispersal) species were disfavoured by higher rainfall and altitude. The negative influence of rainfall on small-scale dispersal plant species richness can be explained by the higher intensity of water flows on inselberg slopes under high rainfall, sweeping recently fallen seeds downslope during intense storm events (Isichei et al. 1990). The negative effect of altitude can be explained by the steeper slopes of dome-shaped taller inselbergs (Bremer and Sander 2000), with similar negative consequences on seed fate. On the contrary, large-scale dispersal plant species richness was favoured by these two factors. The favourable effect of altitude can be explained 
341 by its positive effect on atmospheric turbulence, which could be beneficial for anemochorous (wind-

342 dispersing) species (Horn et al. 2012). The favourable influence of a more rainy climate can be

343 explained by its positive effect on seed-dispersing animals such as bats, birds and monkeys, in turn

344 benefitting zoochorous species (Tabarelli et al. 2003, Almeida-Neto et al. 2008, Correa et al. 2015).

345 In conclusion, our study disentangled how multiple drivers related to island biogeography and

346 environmental filtering contribute directly or indirectly to the plant species richness of island-like

347 rock-savanna vegetation patches covering neotropical inselbergs. Considering all plants, the effect of

348 size was the most important factor, while isolation and environmental filtering had no detectable

349 effect. However, when plants were separated according to their growth form or dispersal ability,

350 environmental filtering also appeared as a influental factor, even largely outweighing size effect in the

351 case of epiphytic species (Fig. 4). The species richness of all plants as well as of all ecological groups

352 increased with higher rock-savanna vegetation area and this size effect was mostly mediated by an

353 increase in habitat diversity, even after accounting for increased sampling effort. Higher rainfall and

354 altitude favoured epiphytic richness, as well as that of large-scale dispersal plant species, while it was 355 detrimental for small-scale dispersal plant species.

356

\section{Funding}

This work was supported by a FEDER grant n॰1348 (Contrat Plan Etat Région) with Ecofor/Gis

Silvolab-Guyane, IRD and MNHN as partners. Additional supports were provided by CNRS and

360 MNHN for fieldwork.

\section{Acknowledgements}

We thank J.P. Gasc, J.J. de Granville and F. Crozier for help with fieldwork. We also thank S.

364 Gonzalez, the curator of the Cayenne Herbarium (CAY), for providing data base information and 
365 Valery Gond for providing SIG data. Finally, we are grateful to two anonymous reviewers for their 366 helpful comments on the first draft of our article.

\section{References}

Allouche, O. et al. 2012. Area-heterogeneity tradeoff and the diversity of ecological communities. Proc. Nat. Acad. Sci. USA 109: 17495-17500.

Almeida-Neto, M. et al. 2008. Vertebrate-dispersal syndromes along the Atlantic forest: broad-scale patterns and macroecological correlates. - Global Ecol. Biogeogr. 17: 503-513.

Auerbach, M. and Shmida, A. 1987. Spatial scale and the determinants of plant species richness. Trends Ecol. Evol. 2: 238-242.

Barbará, T. et al. 2007. Population differentiation and species cohesion in two closely related plants adapted to neotropical high-altitude 'inselbergs’, Alcantarea imperialis and Alvantarea geniculate (Bromeliaceae). - Mol. Ecol. 16: 1981-1992.

Benzing, D.H. 1981. Bark surfaces and the origin and maintenance of diversity among angiosperm epiphytes: a hypothesis. - Selbyana 5: 248-255.

Biedinger, N. et al. 2000. Vascular plants on inselbergs: vegetative and reproductive strategies. - In: Porembski, S. and Barthlott, W. (eds.), Inselbergs: biotic diversity of isolated rock outcrop in tropical and temperate regions. Springer, pp. 117-142.

Boisselier-Dubayle, M.C. et al. 2010. Genetic structure of the xerophilous bromeliad Pitcairnia geyskesii on inselbergs in French Guiana: a test of the forest refuge hypothesis. - Ecography 33: $175-184$.

Bremer, H. and Sander, H. 2000. Inselbergs: geomorphology and geoecology. . - In: Porembski, S. and Barthott, W. (eds.), Inselbergs: biotic diversity of isolated rock outcrops in tropical and temperate regions. Springer, pp. 7-35. 
Bruun, H.H. et al. 2008. Enhancement of local species richness in tundra by seed dispersal through guts of muskbox and barnacle goose. - Oecologia 155: 101-110.

Burnham, K.P. and Anderson, D.R. 2002. Model selection and multimodel inference: a practical information-theoretic approach. Springer.

Cadotte, M.W. and Tucker, C.M. 2017. Should environmental filtering be abandoned? - Trends Ecol. Evol. 32: 429-437.

Cardelús, C.L. et al. 2006. Vascular epiphyte distribution patterns: explaining the mid-elevation richness peak. - J. Ecol. 94: 144-156.

Cheng, H. et al. 2013. Climate change patterns in Amazonia and biodiversity. - Nature Comm. 4: 1411.

Connor, E.F. and McCoy, E.D. 1979. The statistics and biology of the species-area relationship. - Am. Nat. 113: 791-833.

Correa, D.F. et al. 2015. Plant dispersal systems in Neotropical forests: availability of dispersal agents or availability of resources for constructing zoochorous fruits? - Global Ecol. Biogeogr. 24: 203-214.

Delor, C. et al. 2003. Transamazonian crustal growth and reworking as revealed by the 1:500,000scale geological map of French Guiana. - Bureau de Recherches Géologiques et Minières.

Dormann, C.F. et al. 2013. Collinearity: a review of methods to deal with it and a simulation study evaluating their performance. - Ecography 36: 27-46.

Dufour, A. et al. 2006. Plant species richness and environmental heterogeneity in a mountain landscape: effects of variability and spatial configuration. - Ecography 29: 573-584.

Fonty, E. et al. 2009. A 10-year decrease in plant species richness on a neotropical inselberg: detrimental effects of global warming? Global Change Biol. 15: 2360-2374. 
412 Freycon, V. et al. 2010. The impact of climate changes during the Holocene on vegetation in northern French Guiana. - Quaternary Res. 73: 220-225.

Funk, V. et al. 2007. Checklist of the plants of the Guiana Shield (Venezuela: Amazonas, Bolivar, Delta Amacuro; Guyana, Surinam, French Guiana). - Smithsonian Institution.

Gadgil, M. 1971. Dispersal: population consequences and evolution. - Ecology 52: 253-271.

Gazol, A. et al. 2012. Landscape- and small-scale determinants of grassland species diversity: direct and indirect influences. - Ecography 35: 944-951.

Gond, V. et al. 2011. Broad-scale spatial pattern of forest landscape types in the Guiana Shield. - Int. J. Appl. Earth Obs. Geoinf. 13: 357-367.

Grace, J.B. and Pugesek, B.H. 1997. A structural equation model of plant species richness and its application to a coastal wetland. Am. Nat. 149: 436-460.

de Granville, J.J. 1978. Recherches sur la flore et la végétation guyanaise. PhD Thesis. Université des Sciences et Techniques de Montpellier.

de Granville, J.J. 1982. Rain forest and xeric flora refuges in French Guiana. - In: Prance, G.T. (ed.), Biological diversification in the tropics. Columbia University Press, pp. 159-181.

Gray, J.S. 1989. Effects of environmental stress on species rich assemblages. Biol. J. Linn. Soc. 37: $19-32$.

Gröger, A. and Huber, O. 2007. Rock outcrop habitats in the Venezuelan Guayana lowlands: their main vegetation types and floristic components. - Rev. Bras. Bot. 30: 599-609.

Hanski, I. 1989. Metapopulation dynamics: does it help to have more of the same? - Trends Ecol. Evol. 4: 113-114.

Hanski, I. 1991. Single-species metapopulation dynamics: concepts, models and observations. - Biol. J. Linn. Soc. 42: 17-38. 
Héritier, P. 2011. Le climat guyanais: atlas climatique de la Guyane Française. Météo-France.

Honnay, O. et al. 1999. Effects of area, age and diversity of forest patches in Belgium on plant species richness, and implications for conservation and reforestation. - Biol. Conserv. 87: 73-84.

Horn, S. et al. 2012. TurbSeed: a model for wind dispersal of seeds in turbulent currents based on publicly available climate data. - a model for 237/238: 1-10.

Houle, G. and Phillips, D.L. 1989. Seed availability and biotic interactions in granite outcrop plant communities. - Ecology 70: 1307-1316.

Huston, M.A. 1999. Local processes and regional patterns: appropriate scales for understanding variation in the diversity of plants and animals. Oikos 86: 393-401.

Ibisch, P.L. et al. 1995. Floristic, biogeographical, and vegetational aspects of Pre-Cambrian rock outcrops (inselbergs) in eastern Bolivia. - Flora 190: 299-314.

Isichei, A.O. et al. 1990. Mineral nutrient flow from an inselberg in south-western Nigeria. - J. Trop. Ecol. 6: 479-492.

Itescu, Y. 2018. Are island-like systems biologically similar to islands? A review of the evidence. Ecography 42: 1-17.

Kounda-Kiki, C. et al. 2008. Humus profiles and successional development in a rock savanna (Nouragues inselberg: French Guiana): a micromorphological approach infers fire as a disturbance event. - Pedobiologia 52: 85-95.

Laliberté, E. et al. 2014. Environmental filtering explains variation in plant diversity along resource gradients. - Science 345: 1602-1605.

Lavorel, S. et al. 1994. Small scale disturbances and the maintenance of species diversity in Mediterranean old fields. - Oikos 70: 455-473. 
Leibold, M.A. et al. 2004. The metacommunity concept: a framework for multi-scale community ecology. - Ecol. Lett. 7: 601-613.

Lindgren, J.P. and Cousins, S.A.O. 2017. Island biogeography theory outweighs habitat amount hypothesis in predicting plant species richness in small grassland remnants. - Landscape Ecol. 32: 1895-1906.

MacArthur, R.H. and Wilson, E.O. 1967. The theory of island biogeography. Princeton University Press.

Martín-Queller, E. et al. 2017. Islands, mainland, and terrestrial fragments: how isolation shapes plant diversity. - Ecol. Evol. 7: 6904-6917.

Meirelles, S.T. et al. 1999. The vegetation of granite rock outcrops in Rio de Janeiro, Brazil, and the need for its protection. - Environ. Conserv. 26: 10-20.

Moritz, C. et al. 2013. Disentangling the role of connectivity, environmental filtering, and spatial structure on metacommunity dynamics. - Oikos 122: 1401-1410.

Murphy, P.G. and Lugo, A.E. 1986. Ecology of tropical dry forest. - Ann. Rev. Ecol. Syst. 17: 67-88.

Neri, A.V. et al. 2017. Soil and altitude drive diversity and functioning of Brazilian Páramos (campo de altitude). - J. Plant Ecol. 10: 771-779.

Obregon, A. et al. 2011. Canopy level fog occurrence in a tropical lowland forest of French Guiana as a prerequisite for high epiphyte diversity. - Agr. Forest Meteorol. 151: 290-300.

Parmentier, I. and Hardy, O.J. 2009. The impact of ecological differentiation and dispersal limitation on species turnover and phylogenetic structure of inselberg's plant communities. Ecography 32: 613-622.

Peppler-Lisbach, C. et al. 2015. Disentangling the drivers of understorey species richness in eutrophic forest patches. - J. Veg. Sci. 26, 464-479. 
Pickett, S.T.A. 1980. Non-equilibrium coexistence of plants. Bull. Torrey Bot. Club 107: 238-248.

Pinheiro, F. et al. 2014. Rock outcrop orchids reveal the genetic connectivity and diversity of inselbergs of northeastern Brazil. - BMC Evol. Biol. 14: 49.

Porembski, S. 2007 Tropical inselbergs: habitat types, adaptive strategies and diversity patterns. Revista Brasil. Bot. 30: 579-586.

Porembski, S. and Barthlott, W. 2000. Inselbergs: biotic diversity of isolated rock outcrops in tropical and temperate regions. Springer.

Porembski, S. et al. 1996. Biodiversity and vegetation of small-sized inselbergs in West African rain forest (Taï, Ivory Coast). - J. Biogeogr. 23: 47-55.

Porembski, S. et al. 1997. Inselberg vegetation and the biodiversity of granite outcrops. - J. Roy. Soc. Western Australia 80: 193-199.

Porembski, S. et al. 2000a. Islands on islands: habitats on inselbergs. - In Porembski, S. and Barthlott, W. (eds.), Inselbergs: biotic diversity of isolated rock outcrops in tropical and temperate regions. Springer, pp. 49-67.

Porembski, S. et al. 2000b. Factors controlling species richness of inselbergs. - In: Porembski, S. and Barthlott, W. (eds.), Inselbergs: biotic diversity of isolated rock outcrop in tropical and temperate regions. Springer, pp. 451-481.

Prance, G.T. 1996. Islands in Amazonia. - Philos. T. Roy. Soc. B 351: 823-833.

Price, J.P. 2004. Floristic biogeography of the Hawaiian Islands: influence of area, environment and paleogeography. - J. Biogeogr. 31: 487-500.

Ricklefs, R.E. 1987. Community diversity: relative roles of local and regional processes. - Science 235: $167-171$. 
Rull, V. and Montoya, E. 2017. Holocene vegetation dynamics on the Apakará summit of the neotropical Guyana Highlands and potential environmental drivers. - Rev. Palaeobot. Palyno. 240: $22-32$.

Sarthou, C. 1992. Dynamique de la végétation pionnière sur un inselberg en Guyane Française. PhD Thesis. Université Pierre-et-Marie-Curie.

Sarthou, C. and Grimaldi, C. 1992. Mécanisme de colonisation par la végétation d’un inselberg granitique en Guyane française. - Rev. Écol. Terre Vie 47: 329-349.

Sarthou, C. and Villiers, J.F. 1998. Epilithic plant communities on inselbergs in French Guiana. - J. Veg. Sci. 9: 847-860.

Sarthou, C. et al. 2001. Genetic structure of the saxicole Pitcairnia geyskesii (Bromeliaceae) on inselbergs in French Guiana. - Am. J. Bot. 88: 861-868.

Sarthou, C. et al. 2003. Shrub vegetation on tropical granitic inselbergs in French Guiana. - J. Veg. Sci. 14: 645-652.

Sarthou, C. et al. 2009. Successional patterns on tropical inselbergs: a case study on the Nouragues inselberg (French Guiana). - Flora 204: 396-407.

Sarthou, C. et al. 2017. From inselberg to inselberg: floristic patterns across scales in French Guiana (South America). - Flora 229: 147-158.

Servant, M. et al. 1993. Tropical forest changes during the Late Quaternary in African and South American lowlands. -Tropical forest Change 7: 25-40.

Shipley, B. 2009. Confirmatory path analysis in a generalized multilevel context. - Ecology 90: 363368.

Shipley, B. 2013. The AIC model selection method applied to path analytic models compared using a d-separation test. Ecology 94: 560-564. 
Shmida, A. and Wilson, M.V. 1985. Biological determinants of species diversity. - J. Biogeogr. 12: 120.

Shure, D.J. and Ragsdale, H.L. 1977. Patterns of primary succession on granite outcrop surfaces. Ecology 58: 993-1006.

Szarzynski, J. 2000. Xeric islands: environmental conditions on inselbergs. - In Porembski, S. and Barthlott, W. (eds.), Inselbergs: biotic diversity of isolated rock outcrops in tropical and temperate regions. Springer, pp. 37-48.

Tabarelli, M. et al. 2003. Variation of seed dispersal spectrum of woody plants across a rainfall gradient in north-eastern Brazil. - J. Arid Environ. 53: 197-210.

Toivonen, J.M. et al. 2017. Environmental drivers of vascular and non-vascular epiphyte abundance in tropical pre-montane cloud forests in northern Peru. - J. Veg. Sci. 28: 1198-1208.

Van Noordwijk, C.G.E. et al. 2015. Species-area relationships are modulated by trophic rank, habitat affinity, and dispersal ability. - Ecology 96: 518-531.

Veneklaas, E.J. and Van Ek, R. 1990. Rainfall interception in two tropical montane rain forests, Colombia. - Hydrol. Process. 4, 311-326.

Whitehouse, E. 1933. Plant succession on central Texas granite. - Ecology 14: 391-405.

Wolf, J.H.D. and Flamenco-S, A. 2003. Patterns in species richness and distribution of vascular epiphytes in Chiapas, Mexico. - J. Biogeogr. 30: 1689-1707.

Zobel, M. 1997. The relative role of species pools in determining plant species richness: an alternative explanation of species coexistence? - Trends Ecol. Evol. 12: 266-269. 
546 Table 1. Description of the variables studied on the 22 inselbergs.

\begin{tabular}{rcccc}
\hline Variable name & $\begin{array}{c}\text { Nature } \\
\text { and unit }\end{array}$ & Range & Mean & $\begin{array}{c}\text { Coefficient of } \\
\text { variation (\%) }\end{array}$ \\
\hline Distance to Atlantic coast & continuous - km & $60-380$ & 247 & 39.36 \\
Rock-savanna vegetation area & continuous - km ${ }^{2}$ & $0.013-0.663$ & 0.198 & 77.03 \\
Number of terrestrial habitats & discrete & $3-10$ & 7.26 & 26.02 \\
Sampling effort & discrete ${ }^{1}$ - person-days & $1-40$ & 5.64 & 153.56 \\
Inselberg density & continuous $^{2}$ - \% & $0.000-0.686$ & 0.321 & 71.71 \\
Rainfall & continuous - mm & $2182-3767$ & 2494 & 15.95 \\
Altitude & continuous - m & $110-670$ & 313.63 & 50.37 \\
Open-canopy forest matrix cover & continuous ${ }^{3}$ - \% & $2.45-100.00$ & 73.47 & 49.69 \\
Plant species richness & discrete & $32-137$ & 76.23 & 30.94 \\
Terrestrial plant species richness & discrete & $31-107$ & 67.91 & 28.13 \\
Epiphytic plant species richness & discrete & $0-30$ & 8.32 & 89.69 \\
Small-scale dispersal plant species richness & discrete & $3-29$ & 13.86 & 42.78 \\
Large-scale dispersal plant species richness & discrete & $25-124$ & 61.82 & 34.95 \\
Woody plant species richness & discrete & $8-35$ & 18.45 & 38.37 \\
\hline
\end{tabular}

$547 \quad{ }^{1}$ Number of person-days spent on sampling

$548 \quad{ }^{2}$ Proportion of surface occupied by surrounding inselbergs within a $15 \mathrm{~km}$ circle

$549{ }^{3}$ Proportion of surface occupied by open-canopy forest within a $15 \mathrm{~km}$ circle 


\section{Figure captions}

Fig. 1. Map of inselbergs in French Guiana. The 22 studied inselbergs are indicated by large red triangles with the name of their respective inselberg cluster and a letter of the alphabet. Small black dots indicate unstudied inselbergs. For more details see Sarthou et al. (2017).

Fig. 2. Conceptual model of the hypotheses representing how multiple ecological drivers can shape plant diversity of island-like neotropical inselberg ecosystems. Arrows represent the flow of causality. We studied plant diversity as the species richness for the whole community but also of specific ecological groups, such as terrestrial (growing directly on bare rock or on shallow soils), epiphytic (growing on shrubs), small-scale dispersal (autochorous and barochorous), and large-scale dispersal (wind- and animal-dispersed) plant species. We used the number of terrestrial habitats as a measure of habitat diversity for all ecological groups except epiphytic species, for which the richness of woody species was used as a measure of habitat diversity instead. See the end of the introduction for the details of hypotheses and Table 1 for the description of the variables used.

Fig. 3. Drivers of plant diversity in island-like inselberg ecosystems $(n=22)$. (a) Selected path model explaining the species richness of all species. The model was well supported by the data (Fisher's $\mathrm{C}=3.88$, $\mathrm{df}=4, \mathrm{P}=0.423$ ). None of the independence claims implied by the model was statistically significant at $\mathrm{P}=0.05$. Path coefficients are (partial) range-standardized regression coefficients (effect sizes). Arrow widths are proportional to path coefficients. Coefficients of determination $\left(\mathrm{r}^{2}\right)$ of each endogenous variable are reported. (b-d) Selected pairwise relationships between open-rock vegetation area, inselberg density, number of habitats and plant species richness. $\beta_{\mathrm{st}}$ is the range-standardized regression coefficient. ** and *** indicate statistical significance at $\mathrm{P}=0.01$ and 0.001 , respectively. ${ }^{\text {ns. }}$. not significant.

Fig. 4. Variance partitioning of plant species richness across ecological drivers related to island size (rock-savanna vegetation area, $\mathrm{H}_{1}$ ), island isolation (inselberg density, $\mathrm{H}_{2}$ ), environmental filtering (rainfall and altitude, $\mathrm{H}_{3}$ ) and dispersal filtering (forest matrix openness, $\mathrm{H}_{4}$ ). The 
proportion of variance of each class of factors is derived from the sum of squares of the multiple regression of species richness according to the SEM model selected (see Figures 3, 5 and 6).

Fig. 5. Selected path models explaining the species richness of terrestrial (a) and epiphytic (b) plant species richness $(\mathrm{n}=22)$. Both models were well supported by the data (model a: Fisher's $\mathrm{C}=$ 2.2, $\mathrm{df}=4, \mathrm{P}=0.692$; model b: Fisher's $\mathrm{C}=28.3, \mathrm{df}=28, \mathrm{P}=0.446)$. None of the independence claims implied by the model was statistically significant at $\mathrm{P}=0.05$ (Table S2). For further details, see Figure $3 .{ }^{\dagger}, *, * *$ and $* * *$ indicate statistical significance at $\mathrm{P}=0.10$, 0.05, 0.01 and 0.001 , respectively.

Fig. 6. Selected path models explaining the species richness of small-scale (a, autochorous) and largescale (b, anemochorous, zoochorous, hydrochorous) dispersal plant species richness $(\mathrm{n}=22)$. Both models were well supported by the data (model a: Fisher's $\mathrm{C}=22.5$, $\mathrm{df}=22, \mathrm{P}=0.430$; model b: Fisher's $\mathrm{C}=21.1 \mathrm{df}=22, \mathrm{P}=0.512)$. None of the independence claims implied by the model was statistically significant at $\mathrm{P}=0.05$. For further details, see Figure 3. *, ** and *** indicate statistical significance at $\mathrm{P}=0.05,0.01$ and 0.001 , respectively. 


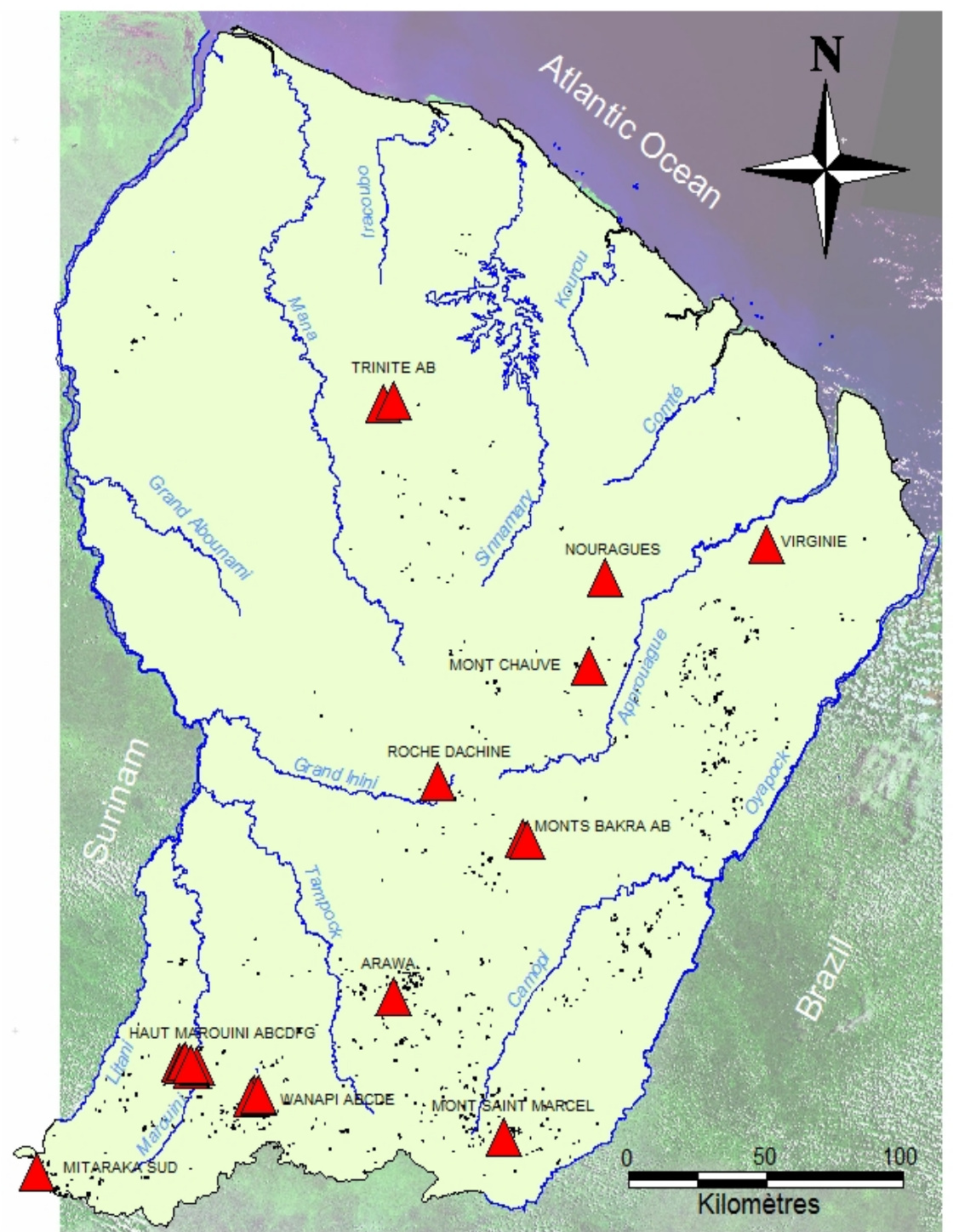

593

$594 \quad$ Fig. 1 


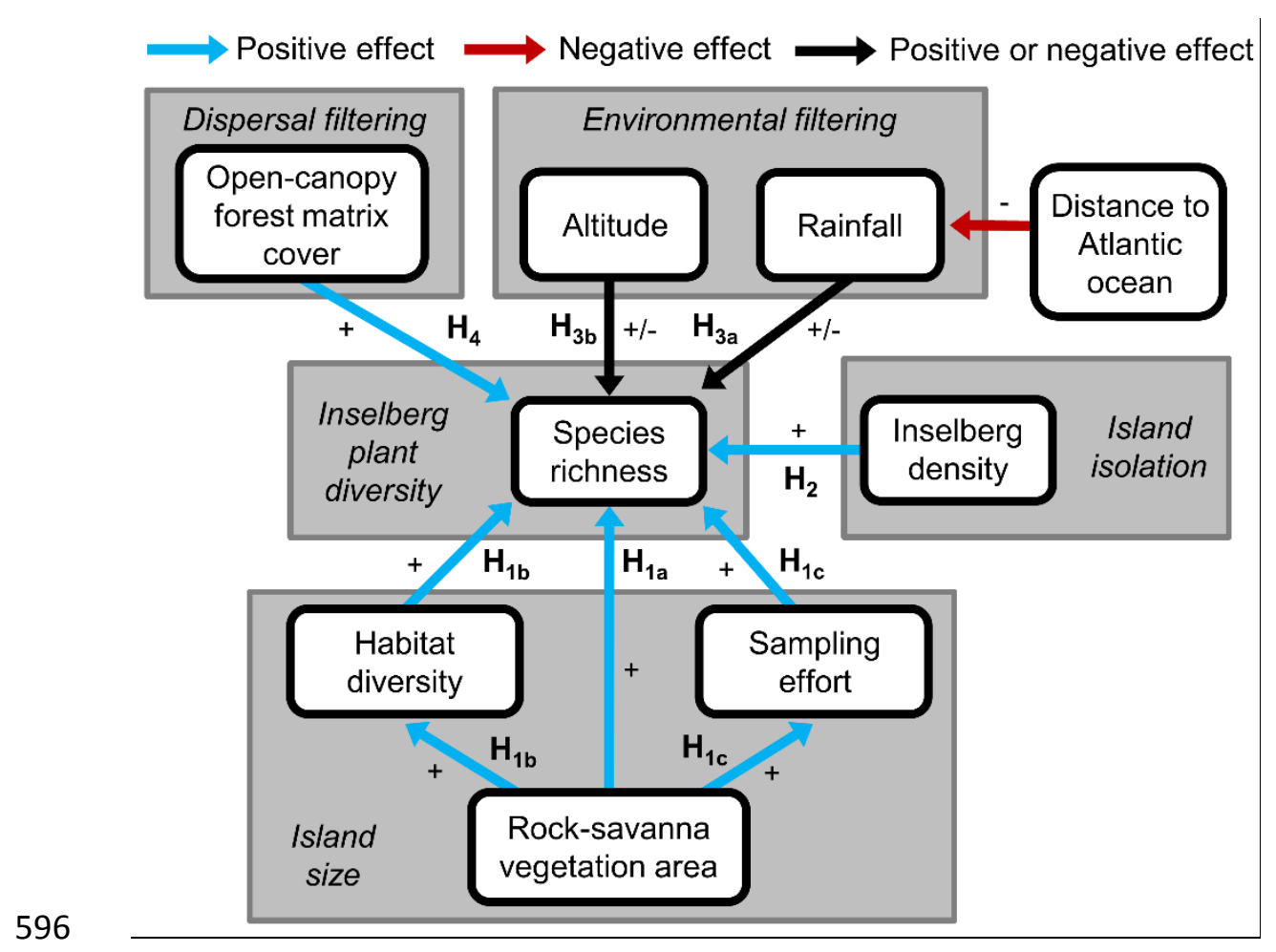

597

Fig. 2 
(a) Total plant species richness
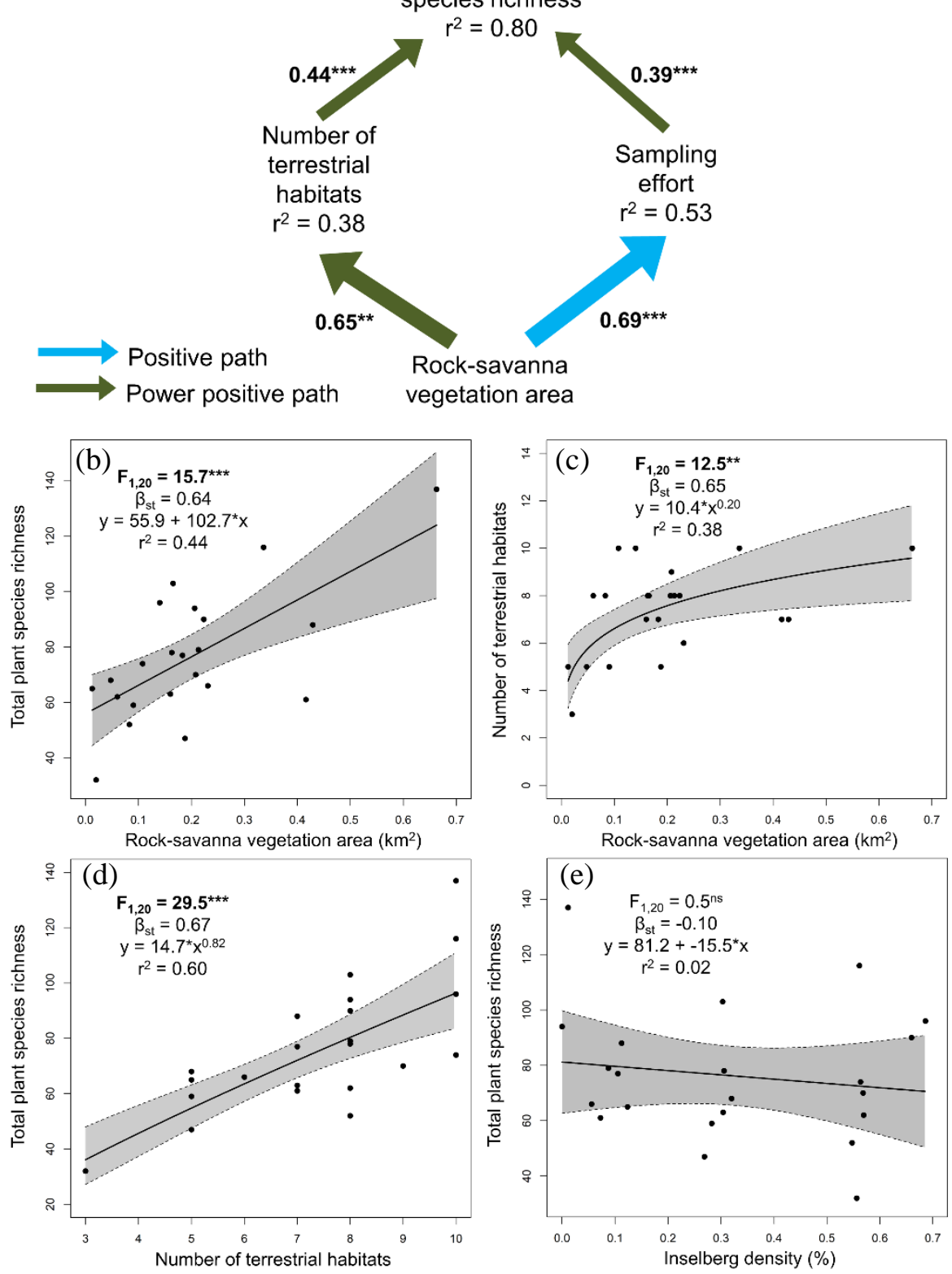

Fig. 3 


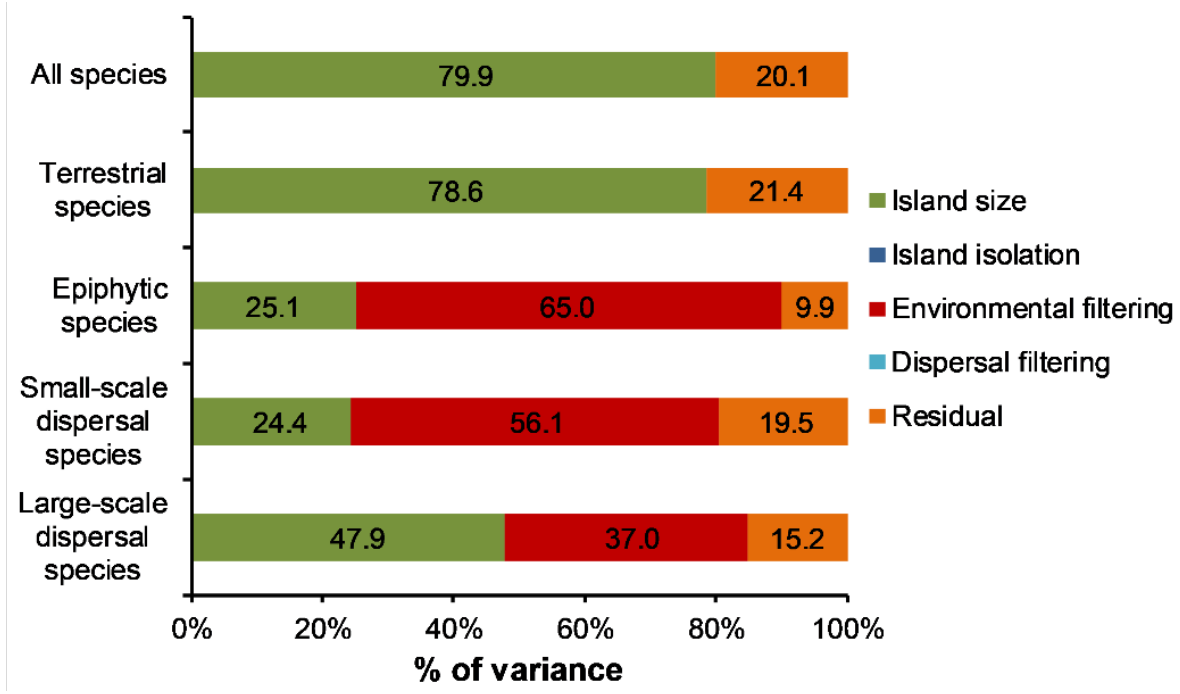

$603 \quad$ Fig. 4 
(a)

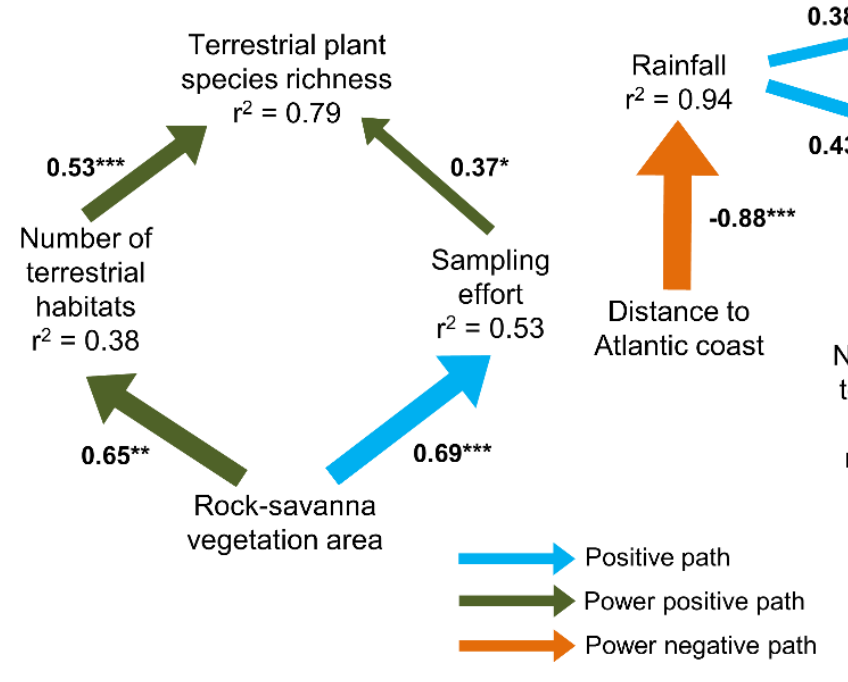

(b)

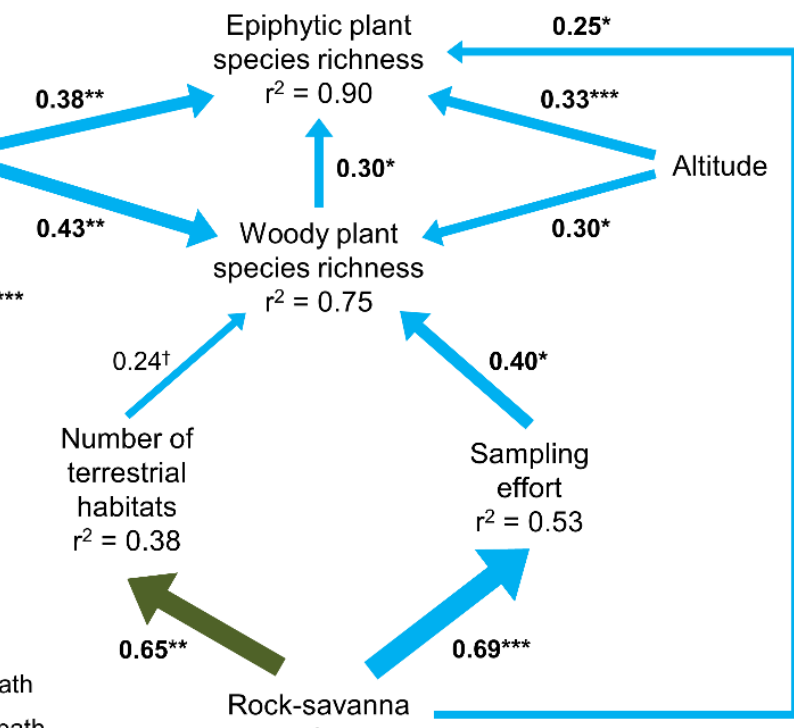

vegetation area

Fig. 5 

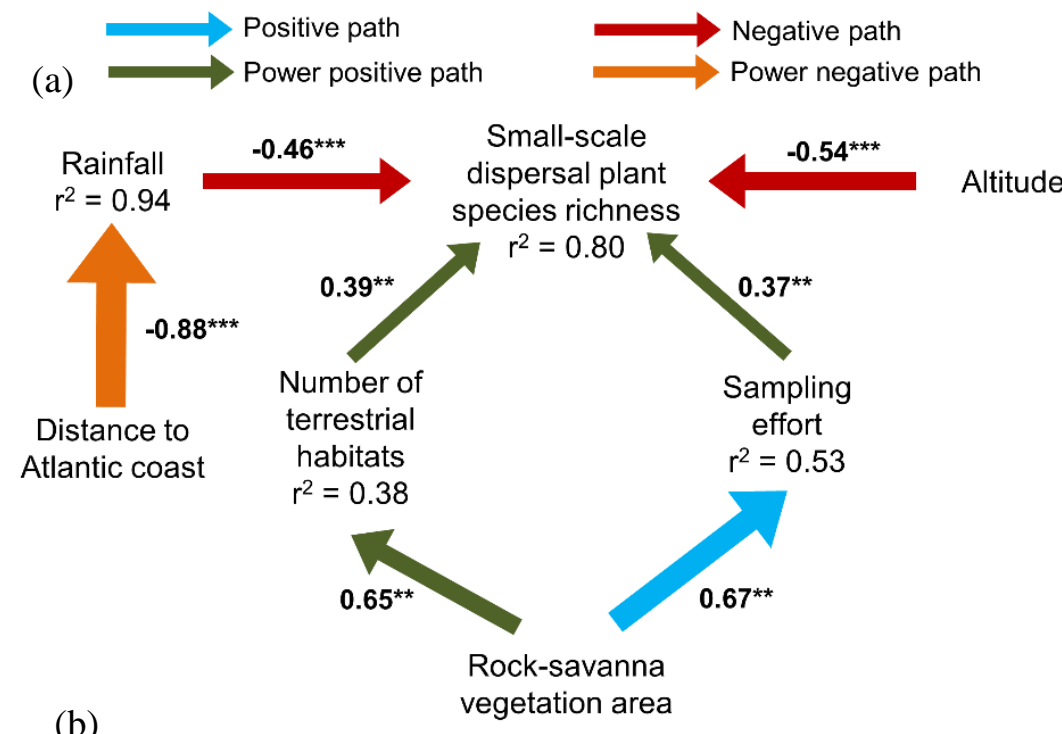

(b)

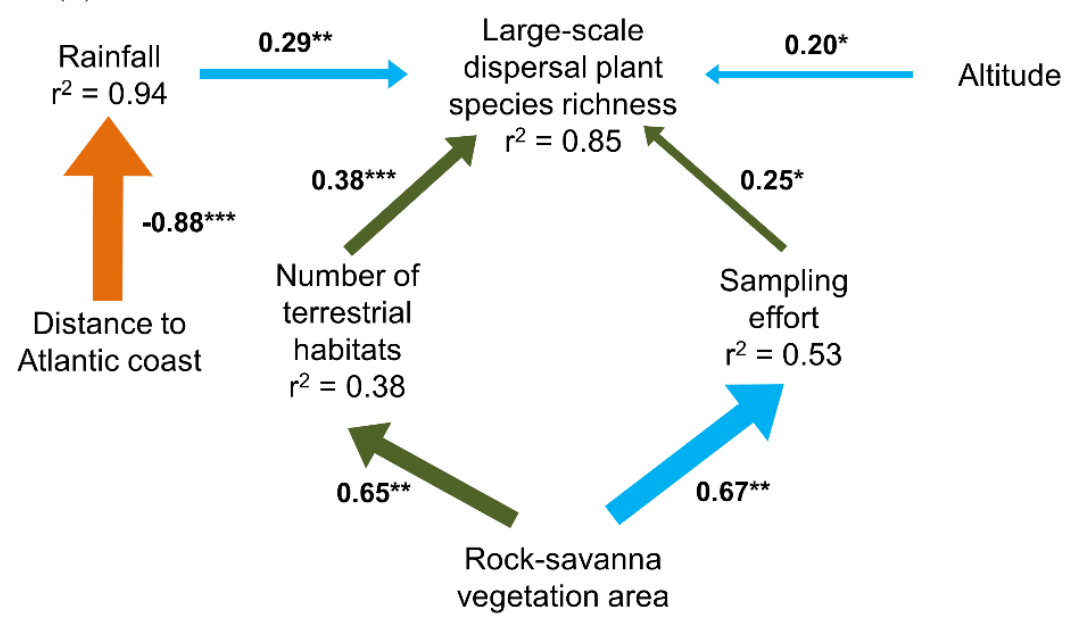

609 Fig. 6 


\section{Appendix}

Table S1. Correlation structure of the variables studied. Spearman's correlation coefficients are shown with values significant at $\mathrm{P}=0.05$ in bold.

\begin{tabular}{|c|c|c|c|c|c|c|c|c|c|c|c|c|c|}
\hline Open-rock vegetation area & -0.55 & & & & & & & & & & & & \\
\hline Number of habitats & -0.07 & 0.35 & & & & & & & & & & & \\
\hline Sampling effort & -0.17 & 0.48 & 0.48 & & & & & & & & & & \\
\hline Inselberg density & 0.62 & -0.43 & 0.31 & -0.10 & & & & & & & & & \\
\hline Rainfall & -0.80 & 0.63 & -0.14 & 0.33 & -0.83 & & & & & & & & \\
\hline Altitude & -0.32 & 0.41 & 0.18 & 0.26 & -0.12 & 0.22 & & & & & & & \\
\hline Open-canopy forest matrix cover & 0.79 & -0.53 & -0.19 & -0.30 & 0.46 & -0.66 & -0.57 & & & & & & \\
\hline Plant species richness & -0.25 & 0.52 & 0.69 & 0.82 & -0.06 & 0.36 & 0.22 & -0.37 & & & & & \\
\hline Terrestrial plant species richness & -0.09 & 0.41 & 0.74 & 0.79 & 0.08 & 0.21 & 0.03 & -0.21 & 0.96 & & & & \\
\hline Epiphytic plant species richness & -0.69 & 0.60 & 0.31 & 0.53 & -0.44 & 0.68 & 0.59 & -0.83 & 0.67 & 0.47 & & & \\
\hline Small-scale dispersal plant species richness & 0.45 & 0.08 & 0.47 & 0.43 & 0.45 & -0.28 & -0.33 & 0.48 & 0.46 & 0.61 & -0.24 & & \\
\hline Large-scale dispersal plant species richness & -0.46 & 0.57 & 0.57 & 0.75 & -0.22 & 0.53 & 0.43 & -0.62 & 0.93 & 0.82 & 0.86 & 0.16 & \\
\hline Woody plant species richness & -0.50 & 0.51 & 0.42 & 0.73 & -0.29 & 0.61 & 0.42 & -0.65 & 0.85 & 0.74 & 0.84 & 0.09 & 0.92 \\
\hline & $\begin{array}{c}\text { Distance } \\
\text { to } \\
\text { Atlantic } \\
\text { coast }\end{array}$ & $\begin{array}{c}\text { Open-rock } \\
\text { vegetation } \\
\text { area }\end{array}$ & $\begin{array}{c}\text { Number of } \\
\text { habitats }\end{array}$ & $\begin{array}{c}\text { Sampling } \\
\text { effort }\end{array}$ & $\begin{array}{c}\text { Inselberg } \\
\text { density }\end{array}$ & Rainfall & Altitude & $\begin{array}{c}\text { Open- } \\
\text { canopy } \\
\text { forest } \\
\text { matrix } \\
\text { cover }\end{array}$ & $\begin{array}{c}\text { Plant } \\
\text { species } \\
\text { richness }\end{array}$ & $\begin{array}{l}\text { Terrestrial } \\
\text { plant } \\
\text { species } \\
\text { richness }\end{array}$ & $\begin{array}{l}\text { Epiphytic } \\
\text { plant } \\
\text { species } \\
\text { richness }\end{array}$ & $\begin{array}{c}\text { Small- } \\
\text { scale } \\
\text { dispersal } \\
\text { plant } \\
\text { species } \\
\text { richness }\end{array}$ & $\begin{array}{c}\text { Large- } \\
\text { scale } \\
\text { dispersal } \\
\text { plant } \\
\text { species } \\
\text { richness }\end{array}$ \\
\hline
\end{tabular}


Table S2. Comparison of model's goodness-of-fits for different regression functions.

\begin{tabular}{|c|c|c|c|c|}
\hline Curve & Function & F-value & P-value & Adjusted $r^{2}$ \\
\hline \multicolumn{5}{|c|}{ Plant species richness $(\mathrm{Y})$} \\
\hline \multicolumn{5}{|c|}{ Rock-savanna vegetation area $(X)$} \\
\hline Linear & $Y=a+b X$ & $F_{1,20}=15.7$ & 0.0008 & 0.41 \\
\hline Quadratic & $Y=a+b X+c X^{2}$ & $\mathrm{~F}_{1,19}=7.5$ & 0.0040 & 0.38 \\
\hline Power & $Y=a * X^{b}$ & $\mathrm{~F}_{1,20}=12.0$ & 0.0024 & 0.34 \\
\hline \multicolumn{5}{|c|}{ Terrestrial habitat number $(X)$} \\
\hline Linear & $Y=a+b X$ & $\mathrm{~F}_{1,20}=21.8$ & 0.0002 & 0.50 \\
\hline Quadratic & $Y=a+b X+c X^{2}$ & $\mathrm{~F}_{1,19}=10.4$ & 0.0009 & 0.47 \\
\hline Power & $Y=a * X^{b}$ & $F_{1,20}=29.5$ & $<0.0001$ & 0.58 \\
\hline \multicolumn{5}{|c|}{ Terrestrial plant species richness $(\mathrm{Y})$} \\
\hline \multicolumn{5}{|c|}{ Rock-savanna vegetation area $(X)$} \\
\hline Linear & $Y=a+b X$ & $\mathrm{~F}_{1,20}=22.4$ & 0.0001 & 0.51 \\
\hline Quadratic & $Y=a+b X+c X^{2}$ & $F_{1,19}=3.8$ & 0.0398 & 0.51 \\
\hline Power & $Y=a * X^{b}$ & $F_{1,20}=9.6$ & 0.0057 & 0.29 \\
\hline \multicolumn{5}{|c|}{ Terrestrial habitat number $(X)$} \\
\hline Linear & $Y=a+b X$ & $\mathrm{~F}_{1,20}=26.6$ & $<0.0001$ & 0.55 \\
\hline Quadratic & $Y=a+b X+c X^{2}$ & $F_{1,19}=12.74$ & 0.0003 & 0.51 \\
\hline Power & $Y=a * X^{b}$ & $F_{1,20}=34.4$ & $<0.0001$ & 0.61 \\
\hline \multicolumn{5}{|c|}{ Epiphytic plant species richness $(Y)$} \\
\hline \multicolumn{5}{|c|}{ Rock-savanna vegetation area $(X)$} \\
\hline Linear & $Y=a+b X$ & $F_{1,20}=22.4$ & 0.0001 & 0.51 \\
\hline Quadratic & $Y=a+b X+c X^{2}$ & $\mathrm{~F}_{1,19}=12.3$ & 0.0004 & 0.51 \\
\hline Power & $Y=a * X^{b}$ & $\mathrm{~F}_{1,20}=4.78$ & 0.0409 & 0.15 \\
\hline \multicolumn{5}{|c|}{ Woody species richness $(X)$} \\
\hline Linear & $Y=a+b X$ & $F_{1,20}=51.15$ & $<0.0001$ & 0.70 \\
\hline Quadratic & $Y=a+b X+c X^{2}$ & $F_{1,19}=25.85$ & $<0.0001$ & 0.70 \\
\hline Power & $Y=a * X^{b}$ & $F_{1.20}=14.3$ & 0.0013 & 0.38 \\
\hline
\end{tabular}


Table S3. Results of the selection procedure of multiple regression models relating plant diversity to ecological drivers $(\mathrm{n}=22)$. All models with $\triangle \mathrm{AICc}<2$ and variance inflation factor $(\mathrm{VIF})<4$ were included in the confidence models set. $\omega_{\mathrm{i}}$ is the model weight indicating the relative support of the model. * ** and $* * *$ indicate statistical significance at $\mathrm{P}=0.05,0.01$ and 0.001 , respectively. ${ }^{\mathrm{ns}}$ : not significant.

\begin{tabular}{|c|c|c|c|c|c|c|c|c|c|c|}
\hline $\begin{array}{l}\text { Open-rock } \\
\text { vegetation } \\
\text { area }\end{array}$ & $\begin{array}{c}\text { Number } \\
\text { of } \\
\text { habitats }\end{array}$ & $\begin{array}{l}\text { Woody } \\
\text { plant } \\
\text { species } \\
\text { richness }\end{array}$ & $\begin{array}{c}\text { Sampling } \\
\text { effort }\end{array}$ & $\begin{array}{l}\text { Inselberg } \\
\text { density }\end{array}$ & Rainfall & Altitude & $\begin{array}{c}\text { Open- } \\
\text { canopy } \\
\text { forest } \\
\text { matrix } \\
\text { cover }\end{array}$ & $\Delta \mathrm{AlCc}$ & $w_{\mathrm{i}}$ & $r^{2}$ \\
\hline \multicolumn{11}{|c|}{ Richness of all plant species } \\
\hline & $0.44^{\star \star \star}$ & & $0.39^{\star * *}$ & \multirow{3}{*}{$-0.12^{\mathrm{ns}}$} & & & & 0.00 & 0.43 & 0.80 \\
\hline & $0.49^{\star \star \star}$ & & $0.34^{\star \star}$ & & & & & 0.39 & 0.34 & 0.83 \\
\hline & $0.45^{\star \star}$ & & $0.35^{\star \star}$ & & $0.13^{\mathrm{ns}}$ & & & 1.26 & 0.23 & 0.82 \\
\hline \multicolumn{11}{|c|}{ Richness of terrestrial plant species } \\
\hline & $0.53^{\star \star \star}$ & & $0.37^{\star \star}$ & & & & & 0.00 & 1.00 & 0.78 \\
\hline \multicolumn{11}{|c|}{ Richness of epiphytic plant species } \\
\hline \multirow[t]{2}{*}{$0.25^{\star}$} & & $0.30^{\star}$ & & & $0.38^{\star \star}$ & $0.33^{\star \star \star}$ & & 0.00 & 0.70 & 0.90 \\
\hline & & $0.40^{* *}$ & & & $0.45^{\star \star \star}$ & $0.33^{\star *}$ & & 1.74 & 0.30 & 0.87 \\
\hline \multicolumn{11}{|c|}{ Richness of small-scale dispersal plant species } \\
\hline & $0.39^{\star \star}$ & & $0.37^{\star \star}$ & & $-0.46^{\star \star \star}$ & $-0.54^{\star \star \star}$ & & 0.00 & 1.00 & 0.80 \\
\hline \multicolumn{11}{|c|}{ Richness of large-scale dispersal plant species } \\
\hline & $0.38^{\star \star}$ & & $0.25^{\star}$ & & $0.29^{\star \star}$ & $0.20^{*}$ & & 0.00 & 1.00 & 0.85 \\
\hline
\end{tabular}
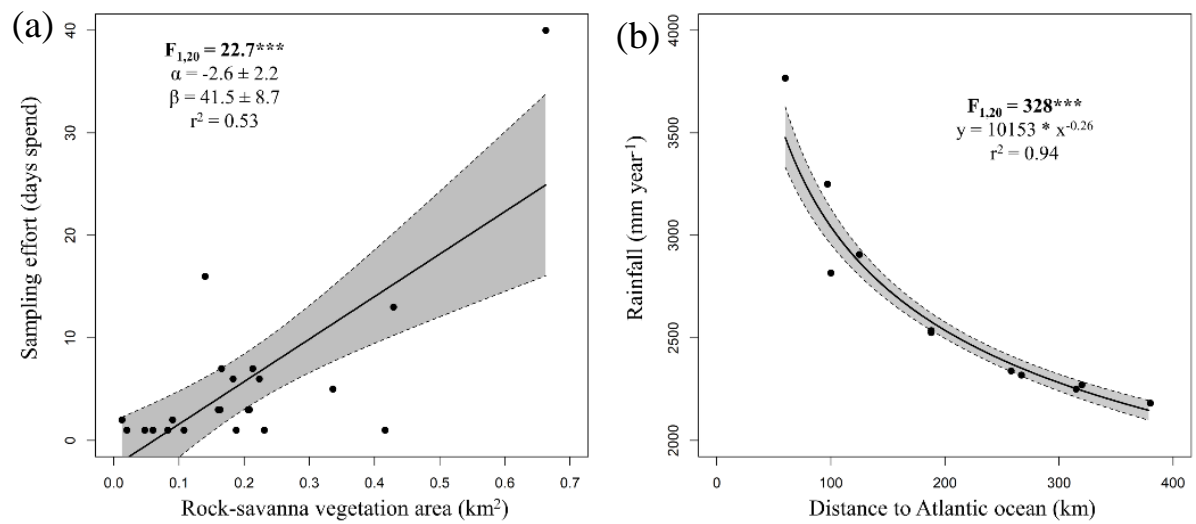

Figure S1. Pairwise relationships between open-rock vegetation area and sampling effort (a), and between distance to the Atlantic Ocean and rainfall (b). $\alpha$ and $\beta$ represent the intercept and slope of linear regression models, respectively ( \pm standard error). $* * *$ indicate statistical significance at $\mathrm{P}=$ 0.001 , respectively. ${ }^{\text {ns: }}$ not significant. 

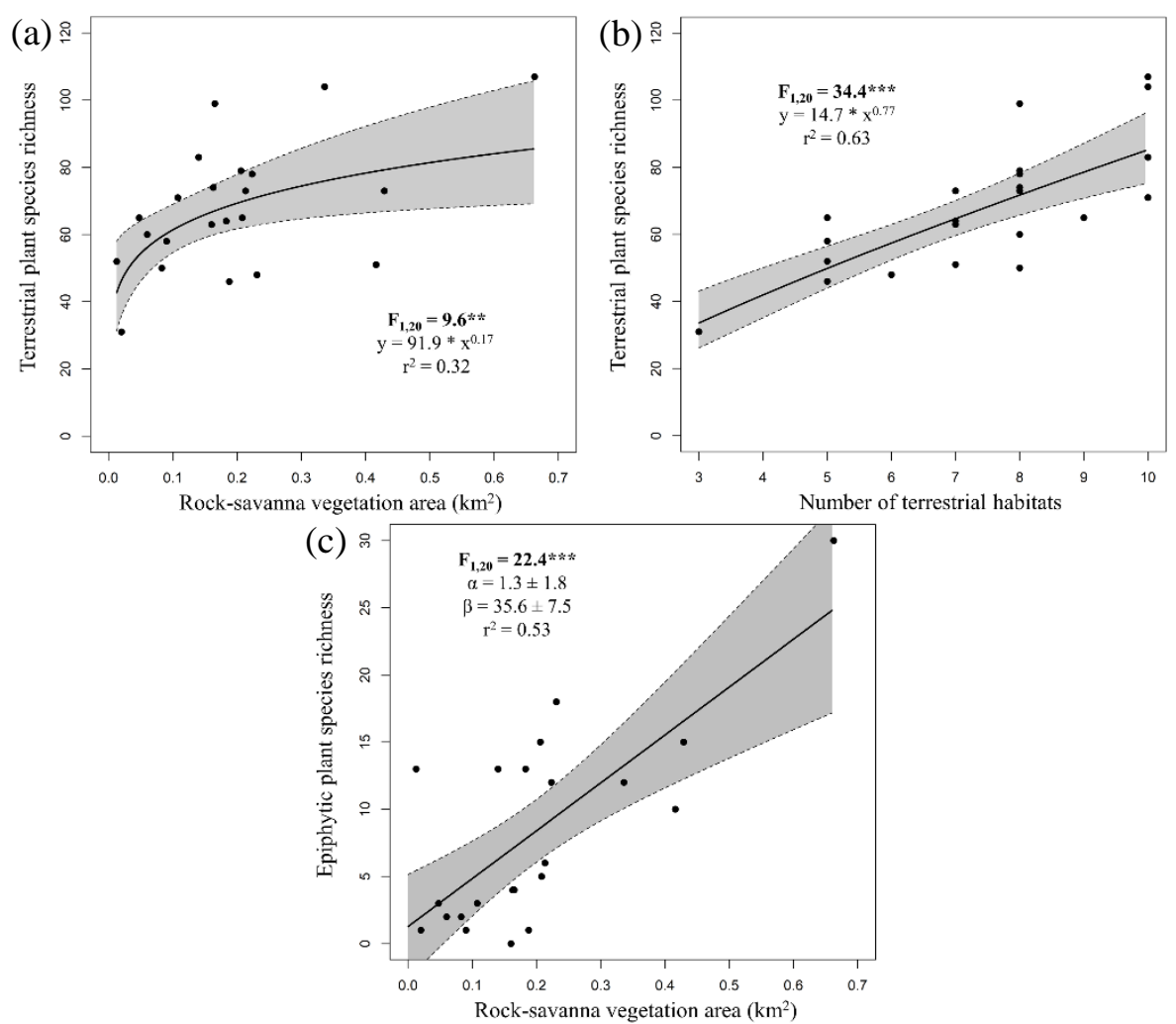

Figure S2. Pairwise relationships between open-rock vegetation area and terrestrial plant species richness (a), between terrestrial habitat number and terrestrial plant species richness (b), and openrock vegetation area and epiphytic plant species richness (c). $\alpha$ and $\beta$ represent the intercept and slope of linear regression models, respectively ( \pm standard error). $* *$ and $* * *$ indicate statistical significance at $\mathrm{P}=0.010$ and 0.001 , respectively..
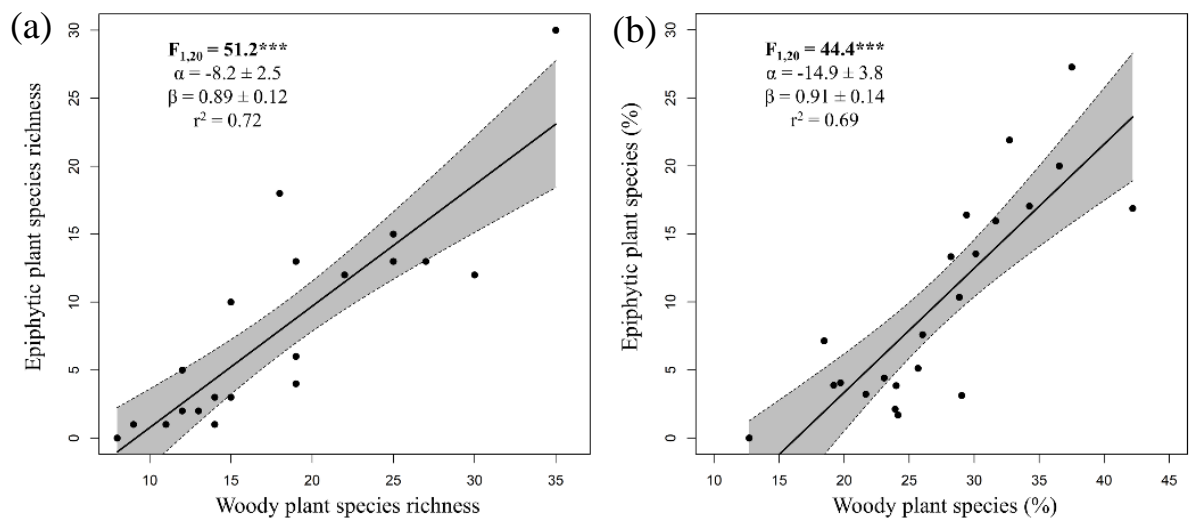

Figure S3. Pairwise relationships of the species richness of woody and epiphytic plants (a), as well as the proportion of woody and epiphytic species within the community (b). $\alpha$ and $\beta$ represents the intercept and slope of linear regression models, respectively ( \pm standard error). $* * *$ indicate statistical significance at $\mathrm{P}=0.001$. 

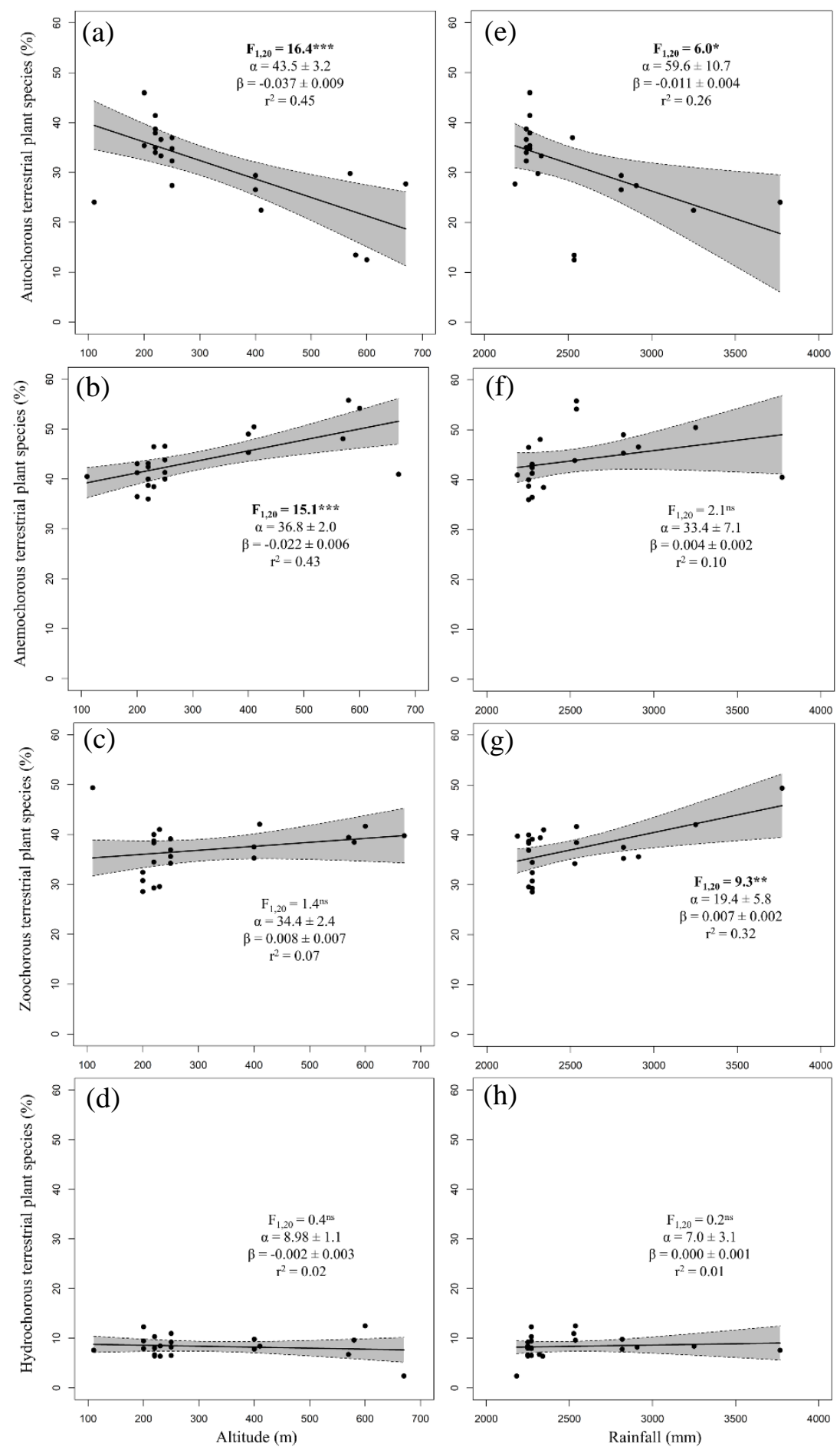

Figure S4. Pairwise relationships of altitude (a, c, e and g) and rainfall (b, d, f and h) with the proportion of species with contrasting dispersal type within the community. $\alpha$ and $\beta$ represents the intercept and slope of linear regression models, respectively ( \pm standard error). $*, * *$ and $* * *$ indicate statistical significance at $\mathrm{P}=0.05,0.01$ and 0.001 , respectively. ${ }^{\text {ns }}$ : not significant. 